Table 2. Clinical outcomes and adverse events



Disclosure of Interests: Sebastian Unizony Grant/research support from: F. Hoffmann-La Roche, Genentech, Consultant for: Kiniksa, Sanofi, GSK, Jinglan Pei Employee of: Genentech, Paris Sidiropoulos Employee of: Genentech, Jennie H. Best Shareholder of: Genentech, Employee of: Genentech, Christine Birchwood Employee of: Genentech, John H. Stone Grant/research support from: F. Hoffmann-La Roche, Genentech, Xencor, Consultant for: Chugain, F. Hoffmann-La Roche, Genentech, Xencor DOI: 10.1136/annrheumdis-2019-eular.1239

\section{SAT0249 IGA VASCULITIS ASSOCIATED WITH INFLAMMATORY BOWEL DISEASE. A RETROSPECTIVE STUDY}

Michel Villatoro Villarr ${ }^{1}$, Cynthia S. Crowson ${ }^{1,2}$, Ashima Makol ${ }^{1}$, Kenneth J. Warrington ${ }^{1}$, Steven R. Ytterberg ${ }^{1}$, Matthew Koster ${ }^{1} .{ }^{1}$ Mayo Clinic, Rheumatology, Rochester MN, United States of America; ${ }^{2}$ Mayo Clinic, Health Sciences Research, Rochester MN, United States of America

Background: Leukocytoclastic vasculitis has been reported in patients with inflammatory bowel disease (IBD) but cases of $\lg A$ vasculitis (IgAV) in IBD are considered rare.

Objectives: The purpose of this study was to describe the baseline characteristics and outcome of a series of patients with IBD and IgAV.

Methods: Biopsy-proven IgAV-patients with prior history of IBD were identified retrospectively at Mayo Clinic, Rochester, MN. Data were abstracted from direct medical chart review. Each IBD-IgAV case was matched to two controls with IgAV but without IBD history based on age, sex and baseline renal function at time of IgAV onset.

Results: A total of 9 patients were included in the study group (6 male, 3 female). Crohn's disease (CD) and Ulcerative Colitis (UC) were present in 7 and 2 patients, respectively. The mean length of time between IBD diagnosis and onset of $\operatorname{lgAV}$ was $17.3 \pm 19.9$ years. For patients on biologic treatment for IBD, the mean length of time between initiation of biologic and onset of IgAV was $3.3 \pm 3.8$ years (range $0-12$ years). Active IBD at IgAV-onset was present in $56 \%(5 / 9)$ of patients.

Tumor necrosis factor inhibitors (TNFi) were the most frequent biologics used for IBD (8, 89\%); infliximab was the most common (7, 78\%). At IgAV-onset, only 5 patients were on treatment with TNFi; two subsequently discontinued, two switched to another TNFi (adalimumab), and one patient continued. At last follow-up, two of three patients that remained on TNFi had full resolution of IgAV despite ongoing TNFi use. Comparison of baseline characteristics between cases with IBD-IgAV and matched non-IBD IgAV controls is demonstrated in Table 1. No differences were seen in regards to development of end-stage renal disease, resolution of hematuria and/or proteinuria, time to complete IgAV response or first $\lg \mathrm{AV}$ relapse.

Conclusion: Baseline characteristics and outcomes of patients with IBD$\lg A V$ are similar to those with IgAV without IBD. Development of IgAV is not limited to patients with clinically active IBD. Whether use of TNFi is related to the pathogenesis of IgAV in some patients with IBD remains unclear. Further research into the pathophysiologic connection between IBD and IgAV is needed.

\section{REFERENCES}

[1] Saint Marcoux B, De Bandt M. Vasculitides induced by TNFalpha antagonists: a study in 39 patients in France. Joint, bone, spine : revue du rhumatisme. 2006;73(6):710-3.
[2] Sy A, Khalidi N, Dehghan N, Barra L, Carette S, Cuthbertson D, et al. Vasculitis in patients with inflammatory bowel diseases: A study of 32 patients and systematic review of the literature. Seminars in arthritis and rheumatism. 2016;45(4):475-82.

[3] Ko JS, Uberti G, Napekoski K, Patil DT, Billings SD. Cutaneous manifestations in inflammatory bowel disease: a single institutional study of non-neoplastic biopsies over 13 years. Journal of cutaneous pathology. 2016;43 (11):946-55.

[4] Ozen S, Pistorio A, lusan SM, Bakkaloglu A, Herlin T, Brik R, et al. EULAR/PRINTO/PRES criteria for Henoch-Schonlein purpura, childhood polyarteritis nodosa, childhood Wegener granulomatosis and childhood Takayasu arteritis: Ankara 2008. Part II: Final classification criteria. Ann Rheum Dis. 2010;69(5):798-806

[5] Laresche C, Locatelli F, Biver-Dalle C, Nachury M, Heyd B, Koch S, et al. Severe Henoch-Schonlein purpura complicating infliximab therapy for ulcerative colitis. Cutis. 2017;99(1):E20-e2.

Table 1: Baseline characteristics of patients with inflammatory bowel disease and immunoglobulin-A vasculitis compared to patients with IgAV without inflammatory bowel disease

\begin{tabular}{|c|c|c|c|}
\hline Characteristic & $\begin{array}{c}\text { IBD- } \operatorname{lgAV} \\
(\mathrm{n}=9)\end{array}$ & $\begin{array}{c}\text { Non-IBD } \lg A V \\
(n=18)\end{array}$ & $p$-value \\
\hline Age at IgAV diagnosis, years ${ }^{\star}$ & $40.8 \pm 17.5$ & $40.7 \pm 17.4$ & 0.96 \\
\hline Male sex & $6(67 \%)$ & $12(67 \%)$ & 1.00 \\
\hline Length of follow-up, years* & $1.3 \pm 2.6$ & $1.1 \pm 1.2$ & -- \\
\hline Creatinine, $\mathrm{mg} / \mathrm{dL}^{*}$ & $1.0 \pm 0.4$ & $0.9 \pm 0.3$ & 0.59 \\
\hline eGFR $\left(\mathrm{ml} / \mathrm{min} / 1.73 \mathrm{~m}^{2}\right)^{\star}$ & $91.4 \pm 31.6$ & $96.4 \pm 22.9$ & 0.72 \\
\hline C-reactive protein, $\mathrm{mg} / \mathrm{L}^{*}$ & $23.3 \pm 12.2$ & $27.0 \pm 27.4$ & 0.62 \\
\hline Renal involvement & $7(78 \%)$ & $10(56 \%)$ & 0.26 \\
\hline Microscopic hematuria & $5(56 \%)$ & $7(39 \%)$ & 0.41 \\
\hline Proteinuria & $7(78 \%)$ & $8(44 \%)$ & 0.10 \\
\hline Palpable purpura & $9(100 \%)$ & $18(100 \%)$ & 1.00 \\
\hline Abdominal Ischemic symptoms & $3(33 \%)$ & $2(11 \%)$ & 0.161 \\
\hline \multicolumn{4}{|l|}{ Disease status at $\lg A V$ diagnosis } \\
\hline Active IBD & $5(56 \%)$ & - & - \\
\hline TNF- $\alpha$ inhibitor at diagnosis & $2 / 5(40 \%)$ & - & - \\
\hline - Ever TNF- $\alpha$ inhibitor & $5 / 5(100 \%)$ & - & - \\
\hline Inactive IBD & $4(44 \%)$ & - & - \\
\hline TNF- $\alpha$ inhibitor at diagnosis & $3 / 4(75 \%)$ & - & - \\
\hline - Ever TNF- $a$ inhibitor & $3 / 4(75 \%)$ & - & - \\
\hline
\end{tabular}

IBD, inflammatory bowel disease; IgAV, immunoglobulin-A vasculitis; eGFR, estimated glomerula filtration rate; TNF- $\alpha$, tumor necrosis factor- $\alpha$ inhibitor.

"Mean \pm standard deviation

Disclosure of Interests: None declared DOI: 10.1136/annrheumdis-2019-eular.7413

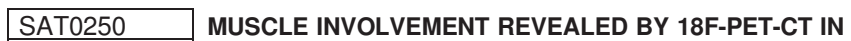 POLYMYALGIA REUMATICA}

Daniel Wendling ${ }^{1}$, Maxime Sondag ${ }^{1}$, Nicolas Giraud ${ }^{1}$, Mickaël Chouk ${ }^{1}$, Hatem Boulahdour ${ }^{2}$, Clément Prati ${ }^{1}$, Frank Verhoeven ${ }^{1} .{ }^{1} \mathrm{CHRU}$, Rheumatology, Besançon, France: ${ }^{2} \mathrm{CHRU}$, Nuclear Medicine, Besançon, France

Background: Imaging techniques in polymyalgia reumatica (PMR) have revealed mainly bursitis, tenosynovitis, capsulitis and enthesitis. This is also the case for 18F-FDG-PET-CT. This technique, which has shown its interest in the diagnosis of PMR, allows an assessment of the metabolic activity of the entire musculoskeletal system and in particular of muscle structures.

Objectives: The objective of this work was to evaluate muscle damage using 18F-FDG-PET-CT in PMR.

Methods: This is a retrospective study including patients with PMR (ACR EULAR 2012 criteria) seen in our department, who had an 18F-FDG PET-CT examination between September 2012 and November 2018. A control group consisting of subjects without rheumatological manifestations who had such an examination as part of neoplastic research or neoplastic disease control was also evaluated. PET evaluation included 17 sites suggestive of PMR, as previously reported [1], leading to a global PET score ranging from 0 to 51 . Muscle hypermetabolism areas were similarly rated according to the same Goerres classification [2] $(0=$ no uptake; 1 = slight uptake, less than liver; 2 = uptake like liver; $3=$ uptake higher than liver). Muscle activity sites have been identified. A comparison of PMR patients with and without muscle involvement was performed using the Mann Whitney or Fisher's exact test. 